\title{
Locally Advanced Angiosarcoma
}

National Cancer Institute

\section{Source}

National Cancer Institute. Locally Advanced Angiosarcoma. NCI Thesaurus. Code C146856.

An angiosarcoma that has spread from its original site of growth to nearby tissues or lymph nodes. 